\author{
АЛЕКСАНДРА ПАВЛОВНА УШАКОВА* \\ Тюменский государственный университет \\ Тюмень, Россия
}

\title{
ИСТОРИЯ ПРЕПОДАВАНИЯ СЛАВЯНСКИХ ЯЗЫКОВ В ТЮМЕНСКОМ ГОСУДАРСТВЕННОМ УНИВЕРСИТЕТЕ
}

\begin{abstract}
В статье представлена история преподавания славянских языков в Тюменском государственном университете. Особое внимание уделяется деятельности профессора Н. К. Фролова (1938-2013), заведующего кафедрой общего языкознания ТюмГу.
\end{abstract}

Ключевые слова: славяноведение, научная школа, персоналии

Кафедра общего языкознания Тюменского государственного университета создана в 1975 г. в результате деления кафедры русского языка, более крупной кафедры университета. Первым кафедрой заведовал к. филол. н., доцент, участник Великой Отечественной войны Безруков Валентин Иванович, затем - к. филол. н., доцент Игнатов Борис Федорович (1978-1983 гг.). В 1983 г. кафедру возглавил выпускник филологического факультета Воронежского государственного университета (выпуск 1965 г.), к. филол. н., доцент Фролов Николай Константинович. С этим именем связан один из значительных и самых продуктивныХ этапов истории кафедры.

Научные интересы Н.К. Фролова определились еще в годы учебы на филологическом факультете. Славянские языки и ономастика стали основными направлениями его работы. В 1972 г. Н.К. Фролов успешно защитил кандидатскую диссертацию „Антропонимия Приворонежья XVII в." под руководством профессора ВГУ Марины Васильевны Федоровой и в 1973 г. был приглашен в Тюменский государственный университет, где начал трудиться преподавателем, затем заведующим кафедрой, деканом филологического факультета (1980-1997 гг., 1993-1998 гг.). В 1990 г. в Днепропетровском государственном университете Н.К.

*apushakova@rambler.ru 
Фролов защитил докторскую диссертацию на тему „Русская топонимия Нижнего Приобья". Он был первым председателем докторского диссертационного Совета по филологическим наукам в ТюмГУ. С 1998 г. - заслуженный деятель науки РФ.

Таким образом, начиная с 1973 года, вся последующая жизнь Николая Константиновича Фролова совпала с годами становления Тюменского государственного университета, созданного на базе педагогического института. Четыре десятилетия жизни было отдано вузовской науке, формированию интеллигенции Западной Сибири.

Н.К. Фроловым было заложено начало преподавания славянских языков в ТюмГУ. Наряду с классическими языками: старославянским, древнегреческим, латинским, - стал преподаваться комплекс славянских языков: сербский, польский, болгарский, украинский, чешский, белорусский. Для чтения данных курсов были приглашены преимущественно преподаватели, закончившие Воронежский государственный университет: С.М. Белякова (чешский), О.И. Усминский (польский), А.П. Ушакова (сербский). Болгарский преподавал сам Н.К. Фролов. Все прибывшие специалисты были кандидатами филологических наук и имели опыт преподавания славянских языков.

Изначально славянские языки изучались в ТюмГУ со 2 по 4 курс. В настоящее время славянские языки преподаются на 2 курсе и 1 семестр - на 3-ем курсе. Также преподавание славянских языков ведется в магистратуре. Студенты кафедры общего языкознания могут выбрать для изучения один славянский язык, в числе которых и сербский.

В последнее десятилетие сербский язык стал особенно популярен среди студентов. Большую роль в это играет тот факт, что Тюменский государственный университет заключил договор о сотрудничестве с Белградским университетом. В рамках этого договора происходит ежегодный интенсивный обмен студентами. Немаловажную роль в мотивации изучения сербского языка играет общность культур, исторические события, объединяющие наши государства, во многом православные истоки наших традиций. В настоящее время приезд студентов из Белградского университета также способствует интересу к изучению сербского языка российскими студентами. Они знакомят ребят с культурой серббского народа. Еще не побывав в Сербии, студенты уже много узнают об этой стране. Для студентов ТюмГУ, показывающих успехи в учебе, предлагается возможность поездки в Белградский университет для дальнейшего углубленного изучения серббского языка.

В преподавании славянских языков необходимо руководствоваться научными мотивами в языковой политике, при этом нельзя забывать и о духовных связях славянских народов, их истории. Поэтому в ТюмГУ преподаватели славянских языков и др. дисциплин, а также студенты, 
изучающие славянские языки, принимают активное участие в проведении Дней славянской письменности и культуры. Вместе с преподаванием славянских языков в ТюмГУ были привнесены традиции Воронежского государственного университета, в частности, празднование Дней славянской письменности и культуры, а также проведение конференций, посвященных этому событию.

Празднование 24 мая проходит повсеместно не только в России, но и в других славянских странах. По своему содержанию День славянской письменности и культуры является государственно-церковным праздником, который государственные и общественные организации проводят совместно с православной церковью. Церковный праздник, связанный с именами славянских первоучителей, солунских братьев Кирилла и Мефодия, своими корнями уходит в XII в., хотя святыми равноапостольными Кирилл и Мефодий были признаны еще раньше, в IX веке.

Светская традиция встречать 24 мая как День славянской письменности и культуры зародилась в России еще в XIX веке. В 1863 г. в связи с тысячелетием создания славянской азбуки был принят указ о ежегодном праздновании Дня памяти святых равноапостольных Кирилла и Мефодия. После 1917 г. праздник был предан забвению, однако великая традиция, хранимая православной церковью, продолжала жить в славянском мире, в лучших произведениях русской литературы и культуры. Государственным он стал с 1990 г., когда Правительство РФ объявило 24 мая Праздником.

Без сомнения, братья Кирилл и Мефодий заложили основы христианской культуры, способствовали распространению православия у славянских народов, поэтому Дни славянской культуры и письменности можно считать всенародным праздником. Мы пользуемся азбукой, которая несла свет истинной веры славянам, вывела их из языческого рабства, познакомила с культурой древних цивилизаций. Все мы храним наследие равноапостольных братьев. Дни славянской письменности и культуры помогают хранить наши традиции, заставляют помнить, что все славяне - братья. В Тюмени в память о святых Кирилле и Мефодии ежегодно, начиная с 1977 года, проводится научная конференция. Первая конференция под названием «Дружбе вечно жить» состоялась в областной научной библиотеке города Тюмени. Ее инициатором выступил Игорь Александрович Шаповалов. Конференция зародилась в рамках дружбы русского и болгарского народов. В этот год в Тюмень прибыла большая группа болгарских строителей, а с ними - и школьники, студенты, преподаватели болгарского языка. Болгары принесли с собой высокий дух древней книжной культуры. И это неудивительно. Древнейшие азбуки - глаголица и кириллица, а также старославянский язык - первый литературный язык всех славян - были созданы на основе 
древнеболгарского языка, который был родным для славянских первоучителей - Кирилла и Мефодия.

В Тюмени в дни праздника проводились церковные службы, на городских площадях и в концертных залах выступали болгарские и русские профессиональные и самодеятельные вокально-инструментальные и танцевальные коллективы. Этот день для тюменцев был воистину праздником дружбы, символом единения славян.

Организатором и вдохновителем конференции в ТюмГУ в 80-е годы стал профессор Н.К. Фролов. В 1978 г. на филологическом факультете Тюменского государственного университета состоялась первая конференция, посвященная 1115-летию создания славянской азбуки.

В дальнейшем при поддержке Комитета по делам национальностей и Общества русской культуры, бессменным председателем которого многие годы являлся Н.К. Фролов, были организованы научные конференции с участием преподавателей и студентов филологического факультета ТюмГУ и множества других докладчиков, проведены общественно значимые культурные мероприятия, посвященные празднованию Дня славянской письменности и культуры. С каждым годом конференция получает все больший размах. Конференции наряду с Тюменью стали проводиться и в других городах, где были филиалы ТюмГУ: Тобольске, Ишиме, Сургуте. По результатам конференции в издательстве Тюменского государственного университета ежегодно выходят сборники научных статей. В последние годы в конференции принимают участие преподаватели, студенты и магистранты из Белградского университета.

Перед началом конференции стало традицией проводить студенческий концерт «Славянский венок». Следует отметить, что это мероприятие «привезли» в Тюмень также преподаватели славянских языков из Воронежского государственного университета, где проводились «Славянские чтения», тоже приуроченные к празднованию Дня славянской письменности и культуры. Как правило, студенты встречают гостей конференции в национальных костюмах и приветствуют их на всех славянских языках. Они выступают с народно-танцевальными программами, чтением стихотворений на сербском, чешском, польском, болгарском, украинском, белорусском языках; их переводами на русский язык. Звучат песнопения на церковно-славянском, греческом, славянских языках в исполнении студентов филологического факультета, изучающих славянские языки в ТюмГУ. Таким образом, славянский концерт также является показателем знаний студентов, изучающих славянские языки. В настоящее время гостями и участниками праздника ежегодно являются и студенты Белградского университета. Их выступления всегда привлекают зрителей. 
Со временем, возникнув в рамках болгаро-советской дружбы, Дни славянской письменности и культуры стали значимым событием в культурной жизни не только Тюменского государственного университета, но и всей Тюменской области в целом. С каждым годом конференция получает все больший размах. Со временем гостями конференции стали гости из Сербии, Польши, Болгарии и др. стран.

И снова первым в установлении сотрудничества между ТюмГУ и Белградским университетом был Н.К. Фролов. В 90-е годы администрацией Тюменской области во главе с губернатором Л.Ю. Рокецким была организована поездка в Белград. Целью поездки было оказание гуманитарной помощи сербскому народу. Решались различные вопросы сотрудничества между двумя городами, в том числе и научное сотрудничество. Именно тогда был заключен долгосрочный договор о сотрудничестве между Белградским университетом и ТюмГУ, которое продолжается до настоящего времени. В состав поездки была включена и автор данной статьи. Мы встречались со студентами филологического факультета, и в те 90-е годы сербские студенты ничего не знали о нашем регионе, нашем университете. В итоге ТюмГУ и Белградский университет в рамках двустороннего договора уже много лет плодотворно сотрудничают в научном и образовательном направлении. Установление научных контактов с Сербией всегда поддерживали ректоры ТюмГУ Геннадий Филиппович Куцев и Геннадий Николаевич Чеботарев, чей вклад в это дело бесценен.

Результативны программы регулярных студенческих обменов между нашими университетами. Ежегодно на семестровую стажировку в Белград отправляются студенты ТюмГУ, а к нам приезжают сербские студенты. Совсем недавно после семестровой стажировки из Белграда вернулись шесть студенток ИФиЖ: студенты 2 курса филологи: Гарбуз Елена, Котегова Мария, Семенова Дарья, Фурцева Ирина, студенты 2 курса филологи с педагогическим направлением: Виктория Марценюк, Юлия Фитина, привезя с собой массу новых впечатлений и весомый багаж знаний. В 2014-2016 гг. четыре студентки Белградского университета Тияна Радосавлевич, Сладжана Маринкович, Андреа Янич, Драгана Оборина обучались в магистратуре ТюмГУ «Русский язык как иностранный» и получили российские дипломы, которые стали отправной точкой для их профессиональной карьеры в Сербии.

Стали победителями стипендиального гранта Министерства образования, науки и технологического развития Республики Сербии для обучения в магистратуре Белградского университета Дарья Корсун и Екатерина Пехова. В осуществлении данных проектов большая помощь была оказана проф., доктором филол. наук Ириной Антанасиевич и академиком Предрагом Пипером, а также выпускниками магистратуры 
ТюмГУ Тияной Радосавлевич, Сладжаной Маринкович и др. В текущем, 2017 в ТюмГУ на стажировке находились студенты Белградского университета: Марияна Бунда, Миня Буякович, Кристина Друлович, Стефан Василевич, Елена Димитриевич, Тияна Павлович. Студенты посещали занятия по предметам специализации, выступили с докладом на 40-ой Международной научно-практической конференции, посвященной памяти святых равноапостольных Кирилла и Мефодия, а также приняли участие в студенческом концерте „Славянский венок”. За активное участие в мероприятиях факультета все студенты были награждены почетными грамотами от руководства Института филологии и журналистики ТюмГУ.

В осуществлении программы сотрудничества с Белградским университетом большую помощь оказывает координатор международных научных программ ТюмГУ Алексанр Шуклин, также побывавший на стажировке в Белградском университете в 2015 г. Всегда ощущаем поддержку иностранного отдела (Е.Э. Южаковой, Павла Кузнецова) в осуществлении наших проектов; с сербской стороны нам активно помогает координатор работы с иностранными студентами Владимир Дайович. Весомым результатом сотрудничества между двумя университетами стало присуждение в 2016 г. профессору кафедры славистики Белградского университета, доктору филологических наук Ирине Антанасиевич звания «Почетный доктор Тюменского государственного университета» за большой вклад в развитие и укрепление академических связей с ТюмГУ. И. Антанасиевич принимала участие в пленарном заседании 39 конференции, посвященной Дням славянской письменности и культуры, она организует совместно с деканатом и кафедрой славистики секции данной конференции в Белградском университете.

В 2013 г. состоялась очередная, 36-я конференция, приуроченная к 1150-летию создания славянской азбуки. Международный форум, собравший десятки известных российских и зарубежных ученых, деятелей литературы, культуры, стал для Николая Константиновича Фролова, доктора филологических наук, профессора, Заслуженного деятеля науки РФ, своеобразным научным итогом, завершающим аккордом в его славистической деятельности, направленной на единение славянского мира. Следующая, 37-я Международная научная конференция, посвященная празднованию Дня славянской письменности и культуры, памяти святых равноапостольных Кирилла и Мефодия и 700-летию Сергия Радонежского, прошла уже без Николая Константиновича. В сборник вошли материалы двух прошедших в Тюменском государственном университете Международных конференций, 36-й - в 2013 г. и 37-й - в 2014 г. Материалы объединены общей идеей необходимости сохранения духовного наследия, завещанного нам славянскими просветителями, иде- 
ей необходимости сохранения идеала святости Русской земли, воплощенного в нравственном подвиге народа.

Последняя 40-я конференция "Православные истоки русской культуры и словесности" проходила 24-30 мая 2017 г. в городах Тюмени и Тобольске и была посвящена памяти святых равноапостольных Кирилла и Мефодия, 430-летию Тобольска, 250-летию сибирского просветителя П.А. Словцова. Студенты в качестве одного из критериев оценки знаний представляют свои доклады наряду с преподавателями. В конференции, состоявшейся в ТюмГУ, была представлена секция по славистике "Сербский язык в Тюмени: сотрудничество и перспективы". С докладами выступили Лазар Герич, председатель сербского землячества в Тюмени, тема: «Опыт культурного сотрудничества Белграда и Тюмени»; Ушакова А.П., профессор кафедры общего языкознания ТюмГУ - «О научном сотрудничестве Тюменского государственного университета и Белградского университета»; Шишкина С.А., кандидат филологических наук, доцент кафедры английской филологии и переводоведения ТюмГУ - «Из опыта преподавания сербского языка инофонам (на Скупе слависта)»; Шуклин А.А., координатор международных научных программ ТюмГУ) - «Изучение русского языка в Сербии: возрождение традиции и новая актуальность».

С различной тематикой выступили студенты, интересующиеся сербским языком: Беда М.В., студент ИФиЖ ТюмГУ (г. Тюмень), «Лингвострановедческий аспект преподавания славянских языков в школе (на примере русского языка)»; И. Видосавлевич (заочное участие), мастер русского языка гимназии г. Крушевац (Сербия), «О методике преподавания русского языка в сербской школе»; Н. Вуйко, магистрант ИФиЖ ТюмГУ (г. Тюмень - г. Белград, Сербия), «Выражение вопроса в русском и сербском языках»; М. Бунда, М. Буякович, К. Друлович, С. Василевич, Е. Димитриевич, Т. Павлович, студенты филологического факультета Белградского университета (г. Тюмень - Белград, Сербия), «Фразеологизмы серббского языка и их эквиваленты в русском»; Котегова М.С., студент ИФиЖ ТюмГУ (г. Тюмень), «Особенности перевода имен прилагательных с русского на серб́ский язык»; Лейс К.А., аспирант кафедры общего языкознания ИФиЖ ТюмГУ (г. Тюмень), «Структурно-функуциональная характеристика антропонимов в произведениях Милорада Павича»; Радосавлевич Т., переводчик-синхронист (заочное участие) (г. Белград, Сербия), «Проблема перевода омонимов с русского языка на сербский»; Шипов С.О., студент ИФиЖ ТюмГУ (г. Тюмень), «Русские лексические заимствования в сербском языке»; Фурцева И.С., студент ИФиЖ ТюмГУ (г. Тюмень), «Русские фамилии в сербском языке».

Некоторые студенты продолжают повышать свои знания за рубежом. Так, Екатерина Пехова после окончания магистратуры в Белг- 
радском университете выиграла стипендию Министерства образования, науки и технологического развития Республики Сербии для обучения в докторантуре.

В ТюмГУ проводятся ежегодные олимпиады по славянским языкам среди студентов 2-3 курсов филологического факультета в рамках Всероссийской студенческой олимпиады, в которой принимают участие и сербские студенты, в том числе и заочно. Цель и направление олимпиады: повышение интереса студенческой молодежи к славянским языкам, их актуальность особенно возрастает в связи с политикой Российской Федерации и укреплением международных связей; проверка качества знаний и умений, полученных в процессе обучения в вузе; 3) оценка уровня владения студентами речевыми навыками, приобретенными в процессе изучения славянских языков. Олимпиада по славянским языкам проводится в один этап, включающий в себ́я ряд тестовых заданий, а также заданий с развернутым ответом, творческие задания, связанные с переводом стихотворений и со знанием страноведческого материала. Участники олимпиады должны показать знания по различным направлениям: 1) современные славянские языки (фонетика, морфология, лексика; синтаксис; 2) история славянских языков (историческая грамматика славянских языков, историческая лексикология славянских языков); 3) изучение славянской культуры.

Так, победителями Олимпиады стали студенты Белградского университета, приезжавшие к нам по обмену: Ивана Видосавлевич, позднее Нина Стефанович, магистрант Наташа Вуйко (2017 г.).

В свое время профессор Белградского университета Б. Станкович отмечал: «...хочется напомнить, что славяне в первом тысячелетии, благодаря деятельности святых Кирилла и Мефодия, объединялись и сближались, во втором тысячелетии они разъединялись и конфронтировали. Будем надеяться, что в третьем тысячелетии сопоставляясь, они соединятся» (Станкович 2000: 11).

Наше сотрудничество с филологическим факультетом Белградского университета продолжается, в перспективе мы надеемся на продолжение совместной научной работы, совместный выпуск сборников, привлечение к публикациям авторов из других вузов, учебных заведений Сербии. Так, в сентябре 2013 года на стажировке в Белграде побывали профессор кафедры общего языкознания ТюмГУ А.П. Ушакова, тогда старший преподаватель кафедры английской филологии С.А. Шишкина, студентка Дегтярева Юлия. В 2016 г. в кафедральном сборнике научных статей опубликовали свои работы профессор Г. Наумович „Использование видеоматериалов на уроках русского языка как иностранного", Т. Радосавлевич „Межъязыковые омонимы в преподавании русского языка серббской аудитории”, А. Янич „К проблеме перевода языковой игры 
в сербской аудитории”, И. Видосавлевич „Мирославово Евангелие”, Д. Жеберан „Богослужебный язык в сербской првославной церкви”. В Вестнике ТюмГУ (входит в список изданий, рецензируемых ВАК) в 2016 году была опубликована совместная статья к.ф.н., доцента кафедры английской филологии и перевода Шишкиной С.А. и мастера русского языка гимназии г. Крушевац (Сербия) Иваны Видосавлевич под названием „Прецедентные тексты в рассказах Милорада Павича".

В данной статье мы рассказали преимущественно о преподавании сербского языка и сотрудничестве с Белградским университетом, так как это сотрудничество результативно, оно стабильно работает и имеются перспективы дальнейшего развития. В преподавании сербсккого языка мы ориентируемся не только на знание грамматики, лексики, синтаксиса, но и на духовные связи, наши студенты узнают много нового о Сербии и балканских странах. С другой стороны, серббкие студенты узнают о России, ее сибирском крае: Тюмени.

В 2017 г. кафедра общего языкознания выступает партнером научно-информационного сборника „Сибирь и Сербия: диалог культур”. Разделы сборника: филология, религиоведение, культурология, публицистика. Можно с оптимизмом смотреть в завтрашний день кафедры. Научный авторитет коллектива достаточно известен в России и за ее пределами (в настоящее время кафедрой общего языкознания заведует Н.В. Лабунец, доктор филологических наук, профессор). Идут поиски новых путей, научных и образовательных контактов со славянскими странами.

\section{ЛИТЕРАТУРА}

Пипер П. Језичка страна глобализације у словенским земљама// Славистика, књ. IX. Гл уредник Б. Станковић. Београд: Славистичко друштво Србије, 2005. С. $19-28$.

Православные истоки русской культуры и словесности: сборник научных статей по материалам 39-ой Международной научно-практической конференции, посвященной празднованию Дней славянской письменности и культуры/ под общ. ред. доктора филологических наук, профессора Н.В. Лабунец, доктора филологичечских наук, профессора Е.Н. Эртнер; Министерство образования и науки Российской федерации, Тюменский государственный университет. Тюмень: изд-во Тюменского государственного университете, 2016. 276 с.

Станкович Б. К вопросу о состоянии и перспективах сопоставительных исследований русского и других славянских языков // V Международный симпозиум. Состояние и перспективы сопоставительных исследований русского и других языков. Редактор Б. Станкович. Белград, 2000. С. 7-11. 
Филологическик чтения: материалы I Регионального научного семинара/ под общ. ред. д-ра филол. наук, проф. Н.В. Лабунец. Тюмень: изд-во Тюменского государственного университете, 2013. 208 с.

(https://www.utmn.ru/presse/novosti/mezhdunarodnaya-deyatelnost/305952/).

\author{
Alexandra P. Ushakova
}

\title{
THE HISTORY OF TEACHING SLAVIC LANGUAGES IN TYUMEN STATE UNIVERSITY
}

\section{Summary}

The article deals with the history of teaching Slavic languages in Tyumen State University. Special attention is paid to the works of Professor N.K. Frolov (1938-2013), Head of the Department of General Linguistics, Tyumen State University.

Key words: Slavic studies, science school, personalities 